\title{
The Effects of CSR on Customer Satisfaction and Loyalty in China: The Moderating Role of Corporate Image
}

\author{
Ki-Han Chung, Ji-Eun Yu, Myeong-Guk Choi, and Jae-Ik Shin
}

\begin{abstract}
In the face of growing worldwide interest in corporate social responsibility (CSR), this paper explores how CSR factors influence customer satisfaction and loyalty and whether the moderating effects of corporate image in the relationships between CSR and customer satisfaction and customer loyalty are or not. There may be the difference of perceptions of CSR between consumers of developing and developed countries. This study used structural equation modeling (SEM) to test the hypotheses. The findings show that CSR positively affects customer satisfaction and loyalty, and customer satisfaction positively affects customer loyalty. The importance order of CSR factors is as follows: consumer protection, philanthropic responsibility, legal responsibility, ethical responsibility, economic responsibility, and environmental contribution. The moderating effect of corporate image in the relationship between CSR and customer satisfaction is identified. Thus, managers should put CSR factors into action in the perspective of consumers, which will encourage customers to perceive the firms more favorably. The conclusion draws implications for marketing practice and future research.
\end{abstract}

Index Terms-Corporate image, customer loyalty, customer satisfaction, CSR.

\section{INTRODUCTION}

To date, corporate social responsibility (CSR) has primarily been treated as a corporate issue. The majority of the literature on this topic takes a management perspective. It discusses how companies can best respond to specific demands of largely external stakeholders, which CSR initiatives enhance corporate performance, and what motivates companies to become engaged in CSR [1]. A survey shows that 76 percent of executives believe that CSR contributes positively to long-term shareholder value, and 55 percent agree that the sustainability helps their companies build a strong reputation [2]. In addition, the degree of CSR level can display the whole performance of the company and what kind of this company is. It is very popular international tide and economy ways. Indeed, CSR efforts are driven not just by ideological thinking that corporations can be a powerful and positive force for social change, but more by the multi-faceted business returns that corporations can potentially reap from their CSR endeavors [3].

Similarly, CSR can be an important factor in the progress of Chinese economic market. China has also recognized its importance either legally or by national policies since the

Maunscript received November 20, 2013; revised January 15, 2014.

The authors are with the Department of Business Administration, Gyeongsang National University of South Korea, Korea (e-mail: sji@gnu.ac.kr). year 2006 [4]. This paper attempts to understand the level of consumer perceptions related to CSR in China by criteria for evaluating social performance of business firms. The social performance varies along a continuum that ranges from compliance-acting to avoid adverse consequences, to conviction-acting to create positive impact. The continuum also varies in commitments to four criteria for evaluating social responsibility practices: economic, legal (environmental contribution and consumer protection), ethical, and philanthropic [5].

The purpose of this study is to identify how CSR influences customer perceptions of customer satisfaction and customer loyalty, as well as the importance order of CSR factors in China. It is also to examine the moderating effects of corporate image in the relationships between CSR and customer satisfaction and customer loyalty.

\section{THEORETICAL BACKGROUND AND HYPOTHESIS}

\section{A. Corporate Social Responsibility}

The World Bank defines CSR as "the commitment of business to contribute to sustainable economic development working with employees, their families, the local community, and society to improve their quality of life, in ways that are both good for business and good for development" [6]. Kotler and Lee [7] defined CSR as "a commitment to improve societal well-being through discretionary business practices and contributions of corporate resources". CSR activities are broadly conceptualized as the company's status and activities with respect to its perceived societal obligations [8], [9]. In the words of Campbell [10] "CSR sets a minimum behavioral standard that aims at doing no harm to stakeholders and if it has happened then rectifies it as soon as it is identified".

Consumers evaluate companies as well as products in terms of CSR, whereby negative CSR associations are more influential and have a more detrimental effect than positive ones. However, positive associations do boost company and product evaluations [11]. The influence of CSR on consumers' purchase intentions is more complex than previously thought, in that CSR can affect purchase intentions directly or indirectly.

Thus, the theoretical and empirical evidence has suggested that CSR activities in consumers' evaluation situation that are perceived more positively lead to higher customer satisfaction and loyalty. This study focuses on CSR activities in China, such as philanthropic, ethical, legal, and economic responsibility, environmental contribution, and consumer protection. 


\section{B. Customer Satisfaction}

Boshoff and Gray [12] underlined that satisfaction is not inherent in the product or the service itself but, instead, satisfaction primarily consists in the consumer's perceptions of the attributes of the product or service as they relate to that individual. Thus, different consumers will express varying levels of satisfaction for the same experience or service encounter [13]. In the marketing literature, customer satisfaction has been recognized as an important part of corporate strategy [14] and a key driver of firm long-term profitability and market value [15]. Thus, it is expected that CSR is positively related to customer satisfaction.

- H1: Customer's perception of CSR positively influences customer satisfaction.

\section{Customer Loyalty}

As customer loyalty is considered a vital objective for a firm's survival and growth, building a loyal customer base has not only become a major marketing goal [16], but it is also an important basis for developing a sustainable competitive advantage [17] (Dick and Basu, 1994). Understanding loyalty cultivation or retention is thus considered to be a key element in delivering long-term corporate profitability [18], [19] as profits can be increased over the lifetime of a customer through his/her retention [20].

Prior research has demonstrated that CSR has an important impact on consumers' attitudes, purchase intentions, consumer-company identification, loyalty, and satisfaction. Initial studies indicate that consumers take a firm's commitment to CSR initiatives into account when evaluating companies and their products [21].

It is widely agreed that customer satisfaction leads to customer retention [22], purchase intentions [23] and word-of-mouth [24]. Thus, it is expected that CSR and customer satisfaction are positively related to customer loyalty.

- H2: Customer's perception of CSR positively influences customer loyalty.

- H3: Customer satisfaction positively influences customer loyalty.

\section{The Moderating Effect of Corporate Image}

Nguyen [25] defines corporate image as consumer's response to total offerings and is related to business name, architecture, variety of products/services, tradition, ideology, and to the impression of quality communicated by each person interacting with the organization. Previous research indicates that having a favorable corporate image and reputation can provide a company with a distinctive and credible appeal, as well as a more effective form of differentiation and a source of competitive advantage. It is believed that corporate image is not just a matter of window dressing but a reliable indicator of whether a company will survive in the future [26].

According to Dowling [27], the attributes of corporate image and reputation give rise to two classes of factors: one is more factual in nature including corporate capabilities and financial performance while the other is a more emotionally driven such as social accountability and the distinctiveness or personality of the organization. A societal marketing program and corporate communications can create positive consumer attitudes toward corporate image [28]. Companies can craft powerful, compelling images that appeal to consumers' social and psychological needs [29] (Kotler and Keller, 2012).

- H4: The effect of CSR on customer satisfaction is greater for high group of perception of corporate image than for low group.

- H5: The effect of CSR on customer loyalty is greater for high group of perception of corporate image than for low group.

- H6: The effect of customer satisfaction on customer loyalty is greater for high group of perception of corporate image than for low group.

The hypothesized relationships we investigate are shown in Fig. 1.

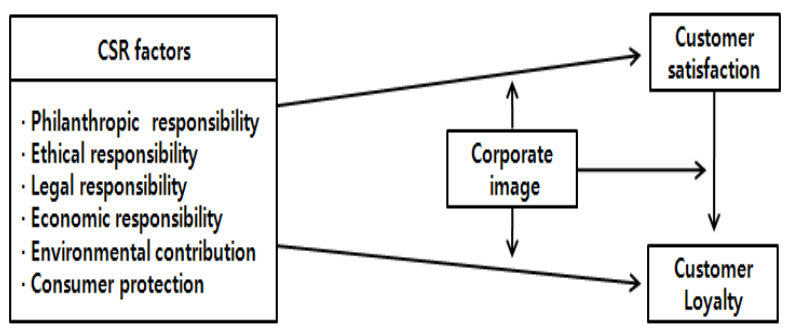

Fig. 1. The proposed model.

\section{Methodology}

\section{A. Data Collection}

The questionnaire was originally developed in English and was translated into Chinese. It was then back-translated by a second bilingual person to ensure greater equivalence of meaning. Both translators were professionals in their fields. The survey included perception of CSR factors, corporate image, customer satisfaction, customer loyalty and demographic information.

For the data collection, web-based survey through e-mail and social networks was conducted in Liaoning, Beijing, Shanghai and Shandong province of East of China. The participants were asked to respond to the survey questionnaires based on their most recent experiences. The online survey form was distributed to 500 participants. A total of 276 usable responses were collected from the 500 participants, producing a response rate of 55.2 percent.

\section{B. Questionnaire Development}

All items used in this study were measured on a seven-point Likert-type scale $(1=$ strongly disagree and $7=$ strongly agree). The survey questions are presented in the Table I.

\section{HYPOTHESIS TESTING}

\section{A. Sample Profile}


TABLE I: SAMPLE PROFILE

\begin{tabular}{|c|c|c|c|c|c|}
\hline \multicolumn{2}{|l|}{ City } & \multicolumn{2}{|c|}{ Position } & \multicolumn{2}{|c|}{ Age } \\
\hline Liaoning & $57.00 \%$ & Student & $35.70 \%$ & $18-24$ & $29.00 \%$ \\
\hline Shandong & $15.00 \%$ & Company employee & $48.30 \%$ & $25-30$ & $60.70 \%$ \\
\hline Beijing & $13.00 \%$ & Government official & $3.70 \%$ & $31-40$ & $8.30 \%$ \\
\hline shanghai & $8.30 \%$ & Others & $12.30 \%$ & \multicolumn{2}{|c|}{ Gender } \\
\hline Guangdong & $3.30 \%$ & & & Male & $52.70 \%$ \\
\hline Jilin & $3.30 \%$ & & & Female & $48.30 \%$ \\
\hline \multicolumn{6}{|c|}{$\mathrm{N}=276$} \\
\hline \multicolumn{2}{|c|}{ Education level } & \multicolumn{2}{|c|}{ Know CSR } & \multicolumn{2}{|c|}{ The level of CSR } \\
\hline Under high school & $0.30 \%$ & Yes & $53.70 \%$ & Low & $45.70 \%$ \\
\hline High school & $2.30 \%$ & No & $46.30 \%$ & Middle & $51.70 \%$ \\
\hline College graduate & $64.70 \%$ & & & High & $2.70 \%$ \\
\hline Postgraduate or Ph.D. & $32.70 \%$ & & & & \\
\hline
\end{tabular}

TABLE II: MEASUREMENT ITEMS

\begin{tabular}{|c|c|c|}
\hline Constructs & Measurement items & Authors \\
\hline \multirow{4}{*}{$\begin{array}{l}\text { Philanthropic } \\
\text { responsibility }\end{array}$} & 1. This firm supports culture and art activities of local community. & \multirow{16}{*}{$\begin{array}{l}\text { Carroll \& Shabana } \\
(2010)\end{array}$} \\
\hline & 2. Managers and employees participate in charitable activities of their local communities. & \\
\hline & 3. This firm supports private and public educational institutions. & \\
\hline & 4. This firm assists to enhance quality of life in the local community. & \\
\hline \multirow{4}{*}{ Ethical responsibility } & $\begin{array}{l}\text { 1. This firm operates in a manner consistent with expectations of societal and ethical } \\
\text { norms. }\end{array}$ & \\
\hline & 2. This firm recognizes and respects new ethical/moral norms. & \\
\hline & 3. This firm prevents unethical behaviors in order to achieve organizational goals. & \\
\hline & 4. This firm make efforts to be good citizenship. & \\
\hline \multirow{4}{*}{ Legal responsibility } & $\begin{array}{l}\text { 1. This firm operates business in a manner consistent with expectations of government } \\
\text { and law. }\end{array}$ & \\
\hline & 2. This firm obeys various federal, state, and local regulations. & \\
\hline & 3. This firm fulfills its legal obligation. & \\
\hline & 4. This firm meets minimal legal requirements related to goods and service. & \\
\hline \multirow{4}{*}{$\begin{array}{l}\text { Economic } \\
\text { responsibility }\end{array}$} & 1. This firm focuses on maximizing earnings. & \\
\hline & 2. This firm is committed to profitability. & \\
\hline & 3. This firm has a strong competitive position. & \\
\hline & 4. This firm seeks a profitable business. & \\
\hline \multirow{4}{*}{$\begin{array}{l}\text { Environmental } \\
\text { contribution }\end{array}$} & 1. This firm practices recycling pollutants and wastes. & \multirow{8}{*}{$\begin{array}{l}\text { Sandhu \& Kapoor } \\
\text { (2010) }\end{array}$} \\
\hline & 2. This firm invests in energy conservation. & \\
\hline & 3. This firm manufactures eco-friendly products. & \\
\hline & EC4. This firm sets out effluent treatment plant. & \\
\hline \multirow{4}{*}{ Consumer protection } & 1. This firm makes efforts to improve product quality. & \\
\hline & 2. This firm settles customers' complaints quickly. & \\
\hline & 3. This firm practices product improvement by customers' requirement. & \\
\hline & 4. This firm makes efforts to improve customer service. & \\
\hline \multirow{3}{*}{ Corporate image } & 1. This firm has an overall clean reputation. & \multirow{3}{*}{$\begin{array}{l}\text { Ishaq(2012), } \\
\text { Yeo et al.(2011) }\end{array}$} \\
\hline & 2. This firm is open to consumers. & \\
\hline & 3. This firm has good transparency. & \\
\hline \multirow{3}{*}{ Customer satisfaction } & 1. The policy of CSR of this firm meets my expectation. & \multirow{3}{*}{$\begin{array}{l}\text { Kaur and Soch } \\
(2012)\end{array}$} \\
\hline & 2. Overall, I am satisfied with CSR activities of this firm. & \\
\hline & 3. Overall, I am satisfied with product and service of this firm. & \\
\hline \multirow{3}{*}{ Customer loyalty } & 1. I would like to positively speak to surrounding people about this firm. & \multirow{3}{*}{$\operatorname{Ishaq}(2012)$} \\
\hline & 2. I would like to patronize this firm. & \\
\hline & 3. I would like to recommend this firm to colleagues who seek my advice. & \\
\hline
\end{tabular}

\section{B. Validity and Reliability of Measures}

All confirmatory factor loadings exceeded the accepted level of 0.5 , and all factor loadings were significant at the level of 0.01 [30] (Anderson and Gerbing, 1988). Furthermore, average variance extracted (AVE) of all constructs exceeded the recommended 0.5 threshold [31] (Hair et al., 1998). Discriminant validity was also assessed by comparing the AVE with the squared correlations between the two constructs was less than the AVEs, which suggests that the constructs were distinct [32] (Ha, 2012). 
TABLE III: CONFIRMATORY FACTOR ANALYSIS

\begin{tabular}{|c|c|c|c|c|c|c|c|}
\hline Variables & Items & Estimate & S.E. & $\begin{array}{l}\text { Standardized } \\
\text { estimate }\end{array}$ & C.R. ${ }^{* *}$ & $\begin{array}{l}\text { Composite } \\
\text { reliability }\end{array}$ & AVE \\
\hline \multirow{3}{*}{$\begin{array}{l}\text { Philanthropic } \\
\text { responsibility }\end{array}$} & PR2 & 0.931 & 0.063 & 0.896 & 14.706 & \multirow{3}{*}{0.871} & \multirow{3}{*}{0.697} \\
\hline & PR3 & 1.000 & - & 0.897 & - & & \\
\hline & PR4 & 0.681 & 0.065 & 0.669 & 10.485 & & \\
\hline \multirow{3}{*}{ Ethical responsibility } & ER1 & 0.980 & 0.095 & 0.807 & 10.328 & \multirow{3}{*}{0.815} & \multirow{3}{*}{0.596} \\
\hline & ER2 & 1.000 & - & 0.846 & - & & \\
\hline & ER3 & 0.664 & 0.079 & 0.593 & 8.352 & & \\
\hline \multirow{3}{*}{ Legal responsibility } & LR1 & 1.000 & - & 0.744 & - & \multirow{3}{*}{0.829} & \multirow{3}{*}{0.618} \\
\hline & LR2 & 0.831 & 0.101 & 0.776 & 8.209 & & \\
\hline & LR3 & 0.84 & 0.084 & 0.728 & 10.051 & & \\
\hline \multirow{3}{*}{ Economic responsibility } & ECR2 & 0.925 & 0.053 & 0.852 & 17.354 & \multirow{3}{*}{0.896} & \multirow{3}{*}{0.742} \\
\hline & ECR3 & 1.000 & - & 0.952 & - & & \\
\hline & ECR4 & 0.825 & 0.052 & 0.794 & 15.895 & & \\
\hline \multirow{2}{*}{$\begin{array}{l}\text { Environmental } \\
\text { contribution }\end{array}$} & EC1 & 0.898 & 0.168 & 0.744 & 5.332 & \multirow{2}{*}{0.838} & \multirow{2}{*}{0.721} \\
\hline & $\mathrm{EC} 2$ & 1.000 & - & 0.734 & - & & \\
\hline \multirow{3}{*}{ Consumer protection } & $\mathrm{CP} 2$ & 0.777 & 0.084 & 0.720 & 9.236 & \multirow{3}{*}{0.832} & \multirow{3}{*}{0.623} \\
\hline & $\mathrm{CP} 3$ & 1.000 & - & 0.811 & - & & \\
\hline & $\mathrm{CP} 4$ & 0.929 & 0.095 & 0.705 & 9.781 & & \\
\hline \multirow{3}{*}{ Corporate image } & CI1 & 0.906 & 0.067 & 0.825 & 13.443 & \multirow{3}{*}{0.876} & \multirow{3}{*}{0.703} \\
\hline & $\mathrm{CI} 2$ & 1.000 & - & 0.874 & - & & \\
\hline & $\mathrm{CI} 3$ & 0.840 & 0.064 & 0.758 & 13.033 & & \\
\hline \multirow{3}{*}{ Customer satisfaction } & $\mathrm{CS} 1$ & 0.893 & 0.046 & 0.875 & 19.503 & \multirow{3}{*}{0.943} & \multirow{3}{*}{0.847} \\
\hline & $\mathrm{CS} 2$ & 1.000 & - & 0.923 & - & & \\
\hline & CS3 & 0.969 & 0.050 & 0.915 & 19.429 & & \\
\hline \multirow{3}{*}{ Customer loyalty } & CL1 & 0.968 & 0.050 & 0.932 & 19.409 & \multirow{3}{*}{0.852} & \multirow{3}{*}{0.664} \\
\hline & CL2 & 1.000 & - & 0.926 & - & & \\
\hline & CL3 & 0.725 & 0.069 & 0.630 & 10.521 & & \\
\hline
\end{tabular}

Note: $\chi 2(263)=439.90, p=0.000, \mathrm{GFI}=0.878, \mathrm{AGFI}=0.842, \mathrm{TLI}=0.936, \mathrm{CFI}=0.964, \mathrm{RMSEA}=0.050,{ }^{\mathrm{a}}$ Reference variables, $* * p<0.01$

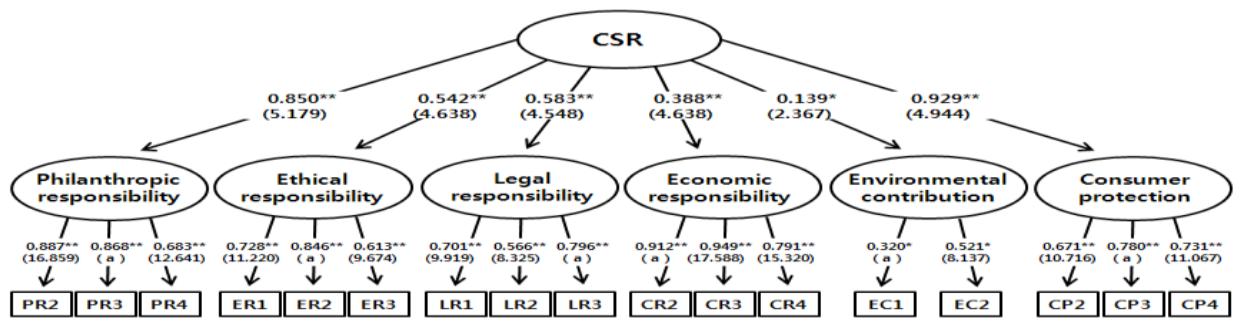

Note: $a$ is reference variable.

Fig. 2. A second-order factor analysis.

TABLE IV: DISCRIMINANT VALIDITY ANALYSIS

\begin{tabular}{|c|c|c|c|c|c|c|c|c|c|c|c|}
\hline Factors & Mean & $\begin{array}{l}\text { Standard } \\
\text { deviation }\end{array}$ & 1 & 2 & 3 & 4 & 5 & 6 & 7 & 8 & 9 \\
\hline $\begin{array}{l}\text { Philanthropic } \\
\text { responsibility }\end{array}$ & 4.603 & 0.996 & 0.697 & & & & & & & & \\
\hline Ethical responsibility & 4.548 & 0.954 & $0.408^{\text {** }}$ & 0.596 & & & & & & & \\
\hline Legal responsibility & 4.470 & 1.022 & $0.514^{\text {** }}$ & $0.439^{* *}$ & 0.618 & & & & & & \\
\hline $\begin{array}{r}\text { Economic } \\
\text { responsibility }\end{array}$ & 5.425 & 1.032 & $0.226^{* *}$ & $0.339^{* *}$ & $0.240^{* *}$ & 0.742 & & & & & \\
\hline $\begin{array}{l}\text { Environmental } \\
\text { contribution }\end{array}$ & 3.918 & 1.304 & 0.114 & $0.171^{*}$ & 0.150 & 0.035 & 0.721 & & & & \\
\hline Consumer protection & 4.459 & 1.075 & $0.567^{* *}$ & $0.388^{* * *}$ & $0.616^{* *}$ & $0.183^{* *}$ & $0.118^{*}$ & 0.623 & & & \\
\hline Corporate image & 4.473 & 0.925 & $0.464^{\text {*** }}$ & $0.362^{* *}$ & $0.461^{\text {** }}$ & $0.358^{* *}$ & $0.314^{\text {*** }}$ & $0.581^{\text {** }}$ & 0.703 & & \\
\hline Customer satisfaction & 4.477 & 1.030 & $0.444^{* * *}$ & $0.262^{* *}$ & $0.442^{* *}$ & $0.273^{* *}$ & $0.179^{* * *}$ & $0.475^{* *}$ & $0.556^{* * *}$ & 0.847 & \\
\hline Customer loyalty & 4.101 & 1.002 & $0.415^{* *}$ & $0.270^{* *}$ & $0.425^{* *}$ & $0.199^{* *}$ & 0.029 & $0.423^{* *}$ & $0.486^{* *}$ & $0.628^{* *}$ & 0.664 \\
\hline
\end{tabular}

Note: The bold scores are the AVEs of each construct. * $p<0.05$, ** $p<0.01$ 


\section{Results of Structural Model}

TABLE V: THE RESUlTS OF HYPOTHESIS TESTING

\begin{tabular}{l|l|l|l|l|c|c|c}
\hline Hypothesis & $\begin{array}{l}\text { Independent } \\
\text { variable }\end{array}$ & Path & $\begin{array}{l}\text { Dependent } \\
\text { variable }\end{array}$ & $\begin{array}{l}\text { Standardized } \\
\text { estimate }\end{array}$ & S.E. & Result \\
\hline $\mathrm{H} 1$ & CSR & $\rightarrow$ & $\begin{array}{l}\text { Customer } \\
\text { satisfaction }\end{array}$ & 0.592 & 0.258 & $5.231^{* *}$ & 0.000 \\
\hline $\mathrm{H} 2$ & CSR & $\rightarrow$ & $\begin{array}{l}\text { Customer } \\
\text { loyalty }\end{array}$ & 0.190 & 0.078 & $2.454^{*}$ & 0.014 \\
\hline $\mathrm{H} 3$ & $\begin{array}{l}\text { Customer } \\
\text { satisfaction }\end{array}$ & $\rightarrow$ & $\begin{array}{l}\text { Customer } \\
\text { loyalty }\end{array}$ & 0.655 & 0.063 & $4.637^{* *}$ & 0.000 \\
\hline
\end{tabular}

Note: $\chi 2(221)=348.94, p=0.000, \mathrm{GFI}=0.907, \mathrm{AGFI}=0.874, \mathrm{NFI}=0.908, \mathrm{TLI}=0.949, \mathrm{CFI}=0.959, \mathrm{RMSEA}=0.051 * p<0.05, * * p<0.01$

TABLE VI: TEST OF THE MODERATING EFFECT OF CORPORATE IMAGE

\begin{tabular}{|c|c|c|c|c|c|c|}
\hline \multirow[t]{2}{*}{ Paths } & \multicolumn{2}{|c|}{ Low } & \multicolumn{2}{|c|}{ High } & \multirow{2}{*}{$\begin{array}{c}\text { Free } \\
\text { model }\end{array}$} & \multirow{2}{*}{$\begin{array}{c}\text { Constrained } \\
\text { model }\end{array}$} \\
\hline & Coefficient & t-value & Coefficient & t-value & & \\
\hline $\mathrm{CSR} \rightarrow$ customer satisfaction & 0.426 & 0.859 & 0.509 & 3.482 & $\chi 2(442)=818.19$ & $\chi^{2}(443)=822.30$ \\
\hline \multicolumn{7}{|c|}{ Chi-square difference test: $\Delta \quad \chi 2(1)=4.11, \mathrm{p}<0.05$ (significant). $\mathrm{H} 4$ is supported. } \\
\hline $\mathrm{CSR} \rightarrow$ customer loyalty & 0.198 & 0.012 & 0.508 & 2.366 & $\chi 2(442)=818.19$ & $\chi 2(443)=819.25$ \\
\hline \multicolumn{7}{|c|}{ Chi-square difference test: $\Delta \quad \chi 2(1)=1.06, \mathrm{p}>0.05$ (insignificant). H5 is not supported. } \\
\hline $\begin{array}{l}\text { Customer } \\
\text { satisfaction } \rightarrow \text { customer } \\
\text { loyalty }\end{array}$ & 0.294 & 5.315 & 0.275 & 5.226 & $\chi 2(442)=818.19$ & $\chi 2(443)=818.35$ \\
\hline
\end{tabular}

Chi-square difference test: $\Delta \quad \chi 2(1)=0.16, p>0.05$ (insignificant). $H 6$ is not supported.

\section{CONCLUSION}

In the following sections, we discuss the implications of our findings in the Chinese CSR setting. We also identify some limitations of current study and suggest topics for future research. This study contributes to an overall understanding of CSR level in China by examining a nomological network of constructs leading to customer loyalty. Building a loyal customer base is an important foundation for developing a sustainable competitive advantage through customer satisfaction. This study examines whether CSR factors can play a role in enhancing customer satisfaction and loyalty or not in China. This study also investigates the moderating effects of corporate image in the relationships between CSR and customer satisfaction and loyalty.

Several theoretical and practical implications arise from these findings. First, environmental contribution and consumer protection were added to Carroll [33]'s CSR constructs (economic, legal, ethical and philanthropic responsibilities) in this study. This is because many Chinese people are concerned with environmental contribution and consumer protection recently. This study shows that CSR positively influences customer satisfaction more than customer loyalty and consumer protection is the most important factor of CSR while environmental contribution is the least factor. It is necessary to educate consumers on the importance of environmental contribution.

Second, the moderating effect of corporate image in the relationship between CSR and customer satisfaction is identified. It is important that the higher the level of corporate image is CSR has a positive effect on customer satisfaction more. Customer perception of corporate image is important and has consequences for customer satisfaction. Customer expectations towards CSR activities lead to stronger evaluations of corporate image. Therefore, firms should ensure that they proactively maximize their CSR budgets. Firms may consider their involvement in some CSR initiatives such as community and environment support and customer relations. In order to increase customer intentions for repeat business, firms' involvement in CSR activities tend to increase favorable attitudes of their customer which results in behavior disposition.

Third, while firms have an obligation to promote social welfare and to behave as good corporate citizens, it is important that they spend the resources allocated to CSR initiatives in ways that yield optimum benefits to society as well as to the stakeholders of the company.

Fourth, China's rapid economic growth has sparked considerable interest in the many countries. Recently Chinese consumers have taken more interests in the companies' CSR activities. CSR has primarily been treated as a corporate issue while CSR initiatives enhance corporate performance. Because Chinese economy has already played a crucial role as growth engines of global economy, its CSR policy is more likely to influence foreign companies' activities. Thus, in order to survive and succeed Korean firms should understand how Chinese consumers perceive CSR activities.

The findings of this study should be interpreted with caution because there are some limitations. First, this study has the limitation of being a cross-sectional research design. With a cross sectional design, the implications of customers' changed attitude on CSR activities over time would not be detected. A longitudinal and qualitative study would provide further theoretical details underlying the findings of this study. 


\section{REFERENCES}

[1] K. Basu and G. Palazzo, "Corporate social responsibility: A process model of sense making," Academy of Management Review, vol. 33, no. 1, pp. 122-136, 2008.

[2] McKinsey. (March 31, 2010). How companies manage sustainability: Mckinsey global survey results. [Online]. Available: https://www.mckinseyquarterly.com

[3] S. Du, C. B. Bhattacharya, and S. Sen, "Maximizing business returns to corporate social responsibility (CSR): The role of CSR communication," International Journal of Management Reviews, vol. 12, no. 1, pp. 8-19, 2010.

[4] P. Bouvain, C. Baumann, and E. Lundmark, "Corporate social responsibility: Evolution of a definitional construct," Business and Society, vol. 38, no. 3, pp. 268-295, 1999.

[5] J. R. Schermerhorn, Introduction to Management, 10st ed, J. Wiley \& Sons, 2010.

[6] A. B. Carroll and K. M. Shabana, "The business case for corporate social responsibility: A review of concepts, research and practice," International Journal of Management Reviews, 2010.

[7] P. Kotler and N. Lee, Corporate Social Responsibility: Doing the Most Good for Your Company and Your Cause, N. J. Hoboken and John Wiley, 2005.

[8] T. J. Brown and P. A. Dacin, "The company and the product: Corporate associations and consumer product responses," Journal of Marketing, vol. 61, no. 1, pp. 68-84, 1997.

[9] S. Sen and C. B. Bhattacharya, "Does doing good always lead to doing better? Consumer reactions to corporate social responsibility," Journal of Marketing Research, vol. 38, no. 2, pp. 225-43, 2001.

[10] J. L. Campbell, "Institutional analysis and the paradox of corporate social responsibility," American Behavioral Scientist, vol. 49, no. 7, pp. 925-938, 2006.

[11] G. J. Biehal and D. A. Sheinin, "The influence of corporate messages on the product portfolio," Journal of Marketing, vol. 71, no. 2, pp. 12-25, 2007.

[12] C. Boshoff and B. Gray, "The relationships between service quality, Customer satisfaction and buying intentions in the private hospital industry," South African Journal of Business Management, vol. 35, no. 4, pp. 27-37, 2004.

[13] L. C. Ueltschy, M. Laroche, A. Eggert, and U. Bindl, "Service quality and satisfaction: An international comparison of professional services perceptions," Journal of Services Marketing, vol. 21, no. 6, pp. 410-423, 2007.

[14] C. Fornell, S. Mithas, F. V. Morgeson, and M. S. Krishnan, "Customer satisfaction and stock prices: High returns Low Risk," Journal of Marketing, vol. 70, no. 1, pp. 3-14, 2006.

[15] H. J. Oh, K. W. Hong, and H. C. Kim, "The influence of multidimensional aspects of service quality, communication on customer satisfaction and customer behavior - focused on the Airline Service," Korean Business Education Review, vol. 28, no. 3, pp. 273-295, 2013.

[16] R. Mandhachitara and Y. Poolthong, "A model of customer loyalty and corporate social responsibility," Journal of Services Marketing, vol. 25, no. 2, pp. 122-133, 2011.

[17] A. Dick and K. Basu, "Customer loyalty: toward an integrated conceptual framework," Journal of Academy of Marketing Science, vol. 22, no. 2, pp. 99-113, 1994.

[18] K. M. Bartol and D. C. Martin, Management, New York: McGraw-Hill Company, pp. 106-107, 1994.

[19] J. S. Chiou and C. Droge, "Service quality, trust, specific asset investment, and expertise: Direct and indirect effects in a satisfaction-loyalty framework," Journal of the Academy of Marketing Science, vol. 34, no. 4, pp. 613-627, 2006.

[20] K. N. Lemon, T. B. White, and R. Winer, "Dynamic customer relationship management: Incorporating future considerations into the service retention decision," Journal of Marketing, vol. 66, no. 1, pp. 1-14, 2002.

[21] M. Oberseder, B. B. Schlegelmilch, and P. E. Murphy, "CSR practices and consumer perceptions," Journal of Business Research, vol. 66, no. 10, pp. 1839-1851, 2013.

[22] E. W. Anderson and M. W. Sullivan, "The antecedents and consequences of customer satisfaction for firms," Marketing Science, vol. 12 , no. 2 , pp. $125-143,1993$.

[23] E. W. Anserson and V. Mittal, "Strengthening the satisfaction-profit chain," Journal of Service Research, vol. 3, no. 2, pp. 107-120, 2000.

[24] E. W. Anderson, "Customer satisfaction and word of mouth," Journal of Service Research, vol. 1, no. 1, pp. 5-17, 1998.
[25] N. Nguyen, "The perceived image of service cooperatives: An investigation in Canada and Mexico," Corporate Reputation Review, vol. 9 , no. 1, pp. 62-78, 2006.

[26] R. K. Yeo, M. Goh, and S. Tso, "Corporate image and reputation of large mainland Chinese enterprise," Journal of Marketing Communications, vol. 17, no. 3, pp. 195-211, 2011.

[27] G. R. Dowling, "Journalists' evaluation of corporate reputations," Corporate Reputation Review, vol. 7, no. 2, pp. 196-205, 2004.

[28] A. Chattananon, M. Lawley, J. Trimetsoontorn, N. Supparerkchaisakul, and L. Leelayouthayothin, "Building corporate image through societal marketing programs," Society and Business Review, vol. 2, no. 3, pp. 230-253, 2007.

[29] P. Kotler and K. L. Keller, Marketing Management 14e, pp. 163-165, 2012.

[30] J. C. Anderson and D. W. Gerbing, "Structural equation modeling in practice: a review and recommended two-step approach," Psychological Bulletin, vol. 103, no. 3, pp. 411-423.

[31] J. F. Hair, R. E. Anderson, R. L. Tatham, and W. C. Black, Multivariate Data Analysis, 5th Ed., Prentice Hall, Upper Saddle River, NJ, 1998.

[32] J. Ha and S. Jang, "The effects of dining atmospherics on behavioral intentions through quality perception," Journal of Services Marketing, vol. 26, no. 3, pp. 204-215, 2012.

[33] A. B. Carroll, "Corporate social responsibility: Evolution of a definition construct,” Business and Society, vol. 38, no. 3, pp. 268-295.

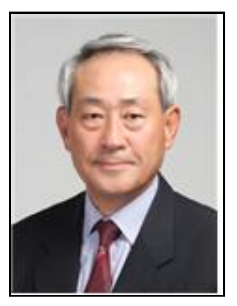

Ki-Han Chung is a professor of Department of Business Administration at Gyeongsang National University, Jinju, South Korea. He received his Ph.D. in Management from Pusan National University, South Korea. His current research interests include marketing channel, market orientation, internal marketing, internet marketing, and service marketing. He has published papers in journals such as Journal of Korean Distribution and Management, Korea Logistics Review, Asia Pacific Journal of Marketing and Logistics, International Journal of Business and Information, Korean Journal of Tourism Research, The Journal of Internet Electronic Commerce Research, The Academy of Customer Satisfaction Management, Journal of the Korea Entrepreneurship, Journal of Industrial Economics and Business, and International Journal of Information Management.

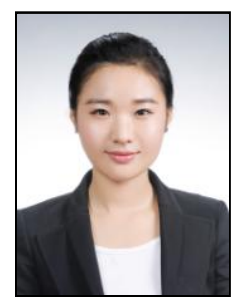

Ji-Eun Yu is a candidate for master of Department of Business Administration at Gyeongsang National University, Jinju, South Korea. Her current research interests include marketing channel, internet marketing, SNSs marketing, and service marketing.

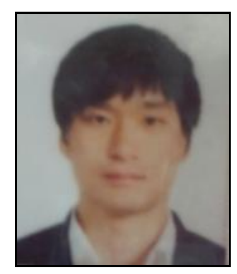

Myeong-Guk Choi is a candidate for Ph.D. of Department of Business Administration at Gyeongsang National University, Jinju, South Korea. $\mathrm{He}$ received his Master in Management from Gyeongsang National University, South Korea. His current research interests include marketing channel, health-care service marketing, internet marketing, and service marketing.

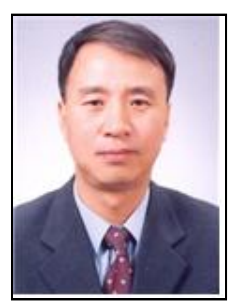

Jae-Ik Shin is a research professor of BK 21 of Department of Business Administration at Gyeongsang National University, Jinju, South Korea. $\mathrm{He}$ received his Ph.D. in Management from Gyeongsang National University, South Korea. His current research interests include internet marketing, tourism marketing, corporate social responsibility, and service marketing. He has published papers in journals such as Asia Pacific Journal of Marketing and Logistics, Korean Journal of Tourism Research, The Journal of Internet Electronic Commerce Research, The Academy of Customer Satisfaction Management, International Journal of Business and Information, Journal of the Korea Entrepreneurship, and International Journal of Information Management. 